\title{
Analytical investigation of beam deformation equation using perturbation, homotopy perturbation, variational iteration and optimal homotopy asymptotic methods
}

\author{
F. FARrokHzAD, P. MOWLAEE, A. BARARI, A. J. CHOOBBASti and \\ H. D. KALIJI
}

\begin{abstract}
.
The beam deformation equation has very wide applications in structural engineering. As a differential equation, it has its own problem concerning existence, uniqueness and methods of solutions. Often, original forms of governing differential equations used in engineering problems are simplified, and this process produces noise in the obtained answers.

This paper deals with solution of second order of differential equation governing beam deformation using four analytical approximate methods, namely the Homotopy Perturbation Method (HPM), Variational Iteration Method (VIM) and Optimal Homotopy Asymptotic Method (OHAM). The comparisons of the results reveal that these methods are very effective, convenient and quite accurate to systems of non-linear differential equation.
\end{abstract}

\section{REFERENCES}

[1] Adomian, G., Stochastic Systems, Academic Press Inc., New York, 1983

[2] Aude, P., Beghein, C., Depecher, P. and Inard, C., Perturbation of the input data of models used for prediction of turbulent air flow in an enclosure, Nummer. Heat Transf., Part B Fundam. (1998), 139-164

[3] Babazadeh, H., Domairry, G., Barari, A., Azami, R. and Davodi, A. G., Numerical analysis of strongly nonlinear oscillation systems using He's max-min method, Frontiers of Mechanical Engineering in China, DOI 10.1007/s11465-009-0033-x, 2010

[4] Barari, A., Ghotbi, A. R, Farrokhzad, F. and Ganji, D. D., Variational iteration method and Homotopy-perturbation method for solving different types of wave equations, J. Appl. Sci. 8 (2010), No. 1, 120-126

[5] Barari, A., Omidvar, M., Ghotbi, A. R. and Ganji, D. D., Application of homotopy perturbation method and variational iteration method to nonlinear oscillator differential equations, Acta Appl. Math. 104 (2008), No. 2, 161-171

[6] Barari, A., Ganjavi, B., Ghanbari Jeloudar, M. and Domairry, G., Assessment of two analytical methods in solving the linear and nonlinear elastic beam deformation problems, J. Engrg., Design and Tech. 8 (2010), No. 2, 127-145

[7] Barari, A., Omidvar, M., Ganji, D. D. and Tahmasebi, A. poor., An Approximate solution for boundary value problems in structural engineering and fluid mechanics, J. Math. Prob. in Engrg. (2008), No. 1, 1-13

[8] Barari, A., Omidvar, M., Ghotbi, A. R. and Ganji, D. D., Assessment of water penetration problem in unsaturated soils, Hydrology and Earth System Sciences Discussions 6 (2009), No. 3, 3811-3833

[9] Bayat, M., Shahidi, M., Barari, A. and Domairry, G., On the approximate analysis of nonlinear behavior of structure under harmonic loading, International Journal of Physical Sciences 5 (2010), No. 7, 1074-1080

[10] Choobbasti, A. J., Barari, A., Farrokhzad, F., and Ganji, D. D., Analytical investigation of a fourth- order boundary value problem in deformation of beams and plate deflection theory, J. Appl. Sci. 8 (2008), 2148-2152

[11] Choobbasti, A. J., Farrokhzad, F., Barari, A. and Ganji, D. D., Application of wave equation in pile foundation using homotopy perturbation method and variational iteration method, J. Appl. Sci. 8 (2008), 2158-2162

[12] Esmaeilpour, M. and Ganji, D. D., Solution of the Jeffery Hamel flow problem by optimal homotopy asymptotic method, Comp. Math. with Appl. 59 (2010), 3405-3411

[13] Fereidoon, A., Ganji, D. D., Kaliji, H. D. and Ghadimi, M., Analytical solution for vibration of buckled beams, International Journal of Research and Reviews in Applied Sciences 4 (2010), No. 3, 17-21

[14] Fillo, J. and Geer, J., Hybrid perturbation-Galerkin technique for nonlinear heat condition problems 2: partial differential equations, Nummer. Heat Transfer. Part B Fundam. (1996), 75-89

[15] Fillo, J. and Geer, J., Hybrid perturbation-Galerkin technique for nonlinear heat condition problems 1: Steady problem, Nummer. Heat Transfer. Part B Funmdam. (1996), 61-73

[16] Fouladi, F., Hosseinzadeh, E., Barari, A. and Domairry, G., Highly nonlinear temperature dependent fin analysis by variational iteration method, Journal of Heat Transfer Research 41 (2010), No. 2, 155-165

[17] Ganji, D. D. and Sadighi, A., Application of homotopy-perturbation and variational iteration methods to nonlinear heat transfer and porous media equations, J. comput. Appl. Math. 207 (2007), 24-34

[18] Ganji, S. S., Barari, A., Ibsen, L. B. and Domairry G., Differential transform method for mathematical modeling of jamming transition problem in traffic congestion flow, Central European Journal of Operations Research, DOI: 10.1007/s10100-010-0154-7, 2010

[19] Ghotbi, A. R., Barari, A., Ganji, D. D., Investigation of Homotopy Perturbation and Variational Iteration Methods into SIR Epidemic Model and Comparison with Adomian Decomposition Method, Journal of Mechanics in Medicine and Biology, DOI: 10.1142/S0219519410003836 (in press)

[20] Ghotbi, A. R., Barari, A. and Ganji, D. D., Solving ratio-dependent predator-prey system with constant effort harvesting using Homotopy perturbation method, J. Math. Prob. in Engrg. (2008), 1-8

[21] He, J. H., Variational iteration method - a kind of non-linear analytical technique: some examples, Int. J. Non-Linear Mech. 34 (1999), 699-708

[22] He, J. H., Some asymptotic methods for strongly nonlinear equations, Int. J. Modern Phys. B. 20 (2006), 1141-1199

[23] He, J. H., Homotopy perturbation method: a new nonlinear analytical technique, Appl. Math. Comput. 135 (2003), 73-79

[24] He, J. H., Addendum: new interpretation of homotopy perturbation method, Int. J. Modern Phys. 20 (2006), 2561-2568 
[25] Ibsen, L. B., Barari, A. and Kimiaeifar, A., Analysis of highly nonlinear oscillation systems using He's max-min method and comparison with homotopy analysis and energy balance methods, Sadhana 35 (2010), 1-16

[26] Iqbal, S., Idrees, M., Siddiqui, A. M. and Ansari, A. R., Some solutions of the linear and nonlinear Klein-Gordon equations using the optimal homotopy asymptotic method, Appl. Math. Comput. 216 (2010), 2898-2909

[27] Marinca, V., Herisanu, N., Bota, C. and Marinca, B., An optimal homotopy asymptotic method applied to the steady flow of a fourth-grade fluid past a porous plate, Appl. Math. Lett. 22 (2009), 245-251

[28] Miansari, M. O., Miansari, M. E., Barari, A. and Domairry, G., Analysis of Blasius equation for Flat-plate flow with infinite boundary value, Int. J. Comput. Methods Eng. Sci. Mech. 11 (2010), No. 2, 79-84

[29] Mirgolbabaei, H., Barari, A., Ibsen, L. B. and Sfahani, M. G., Numerical solution of boundary layer flow and convection heat transfer over a flat plate, Archives of Civil and Mechanical Engineering 10 (2010), 41-51

[30] Momeni, M., Jamshidi, N., Barari, A. and Ganji D. D., Application of He's energy balance method to Duffing harmonic oscillators, Int. J. Comput. Math., DOI: 10.1080/00207160903337239, 2010 (in press)

[31] Omidvar, M., Barari, A., Momeni, M. and Ganji, D. D., New class of solutions for water infiltration problems in unsaturated soils, Geomechanics and Geoengineering: An International Journal 5 (2010), 127-135

[32] Sfahani, M. G., Ganji, S. S., Barari, A., Mirgolbabaei, H. and Domairry, G., Analytical solutions to nonlinear conservative oscillator with fifth-order non-linearity, Earthquake Engineering and Engineering Vibration 9 (2010), No. 3, 367-374

DEPARTMENT OF CiVIL ENGINEERING

BABOL UNIVERSITY OF TECHNOLOGY, BABOL, IRAN

DEPARTMENT OF ELECTRICAL ENGINEERING

AMIRKABIR UNIVERSITY, HAFEZ, TEHRAN, IRAN

DEPARTMENT OF CIVIL ENGINEERING

AALBORG UNIVERSITY

SOHNGRDSHOLMSVEJ 57, 9000 AALBORG, DENMARK

E-mail address: ab@civil.aau.dk, amin78404@yahoo.com

DEPARTMENT OF CIVIL ENGINEERING

BABOL UNIVERSITY OF TECHNOLOGY, BABOL, IRAN

DEPARTMENT OF MECHANICAL ENGINEERING

ISLAMIC AZAD UNIVERSITY, SEMNAN BRANCH, SEMNAN, IRAN 